\title{
PROCESSES IN REPORT TEXT: AN ANALYSIS OF SYSTEMIC FUNCTIONAL LINGUISTIC ON TRANSITIVITY
}

\author{
Gede Sutrisna \\ Program Studi Pendidikan Bahasa Inggris, Fakultas Keguruan dan Ilmu Pendidikan, \\ Universitas Dwijendra \\ e-mail: gedesutrisna@undwi.ac.id
}

\begin{abstract}
Abstrak
Penelitian ini bertujuan untuk mengetahui proses transitivitas yang paling dominan digunakan dalam teks report dan kaitannya dengan prinsip dasar teks report. Desain yang digunakan dalam penelitian ini adalah deskriptif kualitatif dengan penerapan teori Linguistik Sistemik Fungsional pada transitivitas. Data dalam penelitian ini merupakan 29 klausa yang diperoleh dari teks report yang digunakan dalam Ujian Nasional kelas sembilan SMP. Hasil penelitian ini menunjukkan bahwa keenam jenis proses transitivitas digunakan dalam teks report. Namun, proses yang paling banyak digunakan adalah material (44\%) dan relasional $(31 \%)$. Hal ini menandakan kedua proses tersebut berperan penting dalam memberikan informasi dan gambaran yang jelas sehingga para pembaca mampu memahami obyek yang dijelaskan dalam teks report.

Kata Kunci: teks report, transitivitas, linguistik sistemik fungsional
\end{abstract}

\begin{abstract}
This research aimed at investigating the most dominant of transitivity process used in report text and how it relates with the nature of report text. It employed descriptive qualitative design and applied Systemic Functional Linguistics on Transitivity. The data were 29 clauses taken from report texts used in ninth grade's National Exam. The result of this research revealed that six types of transitivity processes found in the report texts. Yet, material $(44 \%)$ and relational $(31 \%)$ were found to dominate the rest of the processes. This implied that those two processes serve important roles in providing clear information and description for the readers to understand the object being described in report text.
\end{abstract}

Keywords: report text, transitivity, systemic functional linguistics

\section{INTRODUCTION}

Practically, as one of various linguistic theories, Systemic Functional Linguistics (SFL) has been known for its extensive use in Discourse Analysis. This approach emerged from the concept of "language as a social semiotic" which enable human beings to exchange three fundamental types of meaning: ideational meaning (the representation and identification of people, things and events); interpersonal meaning (the expression social roles and attitudes); and textual meaning (the coordination of texts both internally and with respect to their contexts of production and reception). According to Mehmood, Amber,
Ameer, \& Faiz (2014), the ideational meaning (the clause as representation) serves for the expression of "content" in language, that is, our experience of the real world, including the experience of our inner world. When we use language, we often use it to speak of something or someone doing something. That is why the ideational meaning can be referred to as experiential meaning coming from the clause as representation. The interpersonal meaning helps to establish and maintain social relations; the individual is identified and reinforced in this aspect by enabling him/her to interact with others by expression of their own individuality. 
Those three types of meanings presented in language are not accidental but are necessarily in place because we need them to perform functions in social life. In constructing experiential meaning, there is one major system of grammatical choice involved: the system of transitivity. It was originally proposed by Halliday which concerned on the type of process expressed in the clause, with the participants in this process (animate and inanimate) and with various attributes and circumstances of the process and the participants (Zheng, Yang \& Ge, 2014). By using transitivity system, researchers have tried to reveal that language structures can produce certain meanings and ideology which are not always explicit for readers. In other words, transitivity can show how speakers or writers encode in language their mental reflection of the world and how they account for their experience of the world around them. In addition, it is used to discover the relation between meanings and wordings that accounts for the organization of linguistic features in a text (Mehmood et al, 2014)

Based on Halliday's theory, transitivity system consists of six processes: material, behavioral, mental, verbal, existential and relational. Those processes represent human experience in a variety of actions. Material and behavioral process deal with physical and physiological actions. Then, while mental and verbal process relate to thinking and speaking actions, existential and relational process concern with the existence of something/someone and their identifying features.

Among the processes, material process is defined as the process of doing, meaning that some entities do something to some other entities. It covers two participants consist of actor and goal. Actor is the doer of the process, and then goal is the person or entity affected by the process (Bustam, 2011). For instance:

$\begin{array}{ccc}\text { The lion } & \text { Caught } & \text { the tourist } \\ \text { Actor } & \text { Process } & \text { goal }\end{array}$

Unlike material process, mental process as the process of sensing deals with thinking or feeling. Suarnajaya (2015) stated that mental processes cover these following aspects.

a. Perception - having to do with the verbs of hearing and seeing

b. Affection - associated with the verbs of liking, fearing

c. Cognition - the verbs of thinking, knowing, understanding

Participants in mental processes consist of senser (the conscious being that is feeling, thinking, or seeing) and phenomenon (which is 'sensed', felt, thought or perceived by the conscious senser). Consider the following example.

$\begin{array}{ccc}\text { She } & \text { likes } & \text { the dance } \\ \text { Senser } & \begin{array}{c}\text { Process: } \\ \text { cognition }\end{array} & \text { Phenomenon }\end{array}$

In relation to verbal process, Suarnajaya (2015) defined it as the process of verbal action, covering the action of saying and all other verbal actions that convey similar meanings with saying, such as telling, asking, and talking, 
etc. Usually three participants are involved in verbal processes:

1) Sayer is responsible for verbal process.

2) Receiver is the person at whom the verbal process is directed.

3) Verbiage is a noun referring to some kind of verbal behavior and derived from the verbal process - 'story' associated with 'telling'.

Nevertheless, there is one other type of verbal process, in which the sayer is in sense acting verbally on another direct participant, with verbs such as: insult, praise, slander, abuse, and flatter. This other participant will be referred to as the target.

$\begin{array}{cccc}\text { They } & \text { Asked } & \text { him } & \begin{array}{c}\text { a lot of } \\ \text { question }\end{array} \\ \text { Sayer } & \begin{array}{c}\text { Process: } \\ \text { verbal }\end{array} & \text { Receiver } & \text { Verbiage }\end{array}$

Consider the following example for target:

$\begin{array}{lll}\text { I } & \text { 'm you to my friends } \\ \text { always } & \\ \text { praising } & \end{array}$

Sayer Process: Target Verbiage
verbal

Being partly like the material process and partly like the mental process, the behavioral process is the least distinct of all the six process types, especially in the language of science. It concerns on human physiological and psychological behavior (Zheng, Yang \& Ge, 2014). Behavioral processes usually have one participant who is typically a conscious one, called the Behaver.
Buff neither laughs nor smiles

Behaver process

Compared to the other processes, existential processes have no representational function but representation of an existence. In other words, it emphasizes that something exists (Suarnajaya, 2015). The word be, or some other verbs such as exist, arise, occur are used to express existence. The statement mostly starts with the introductory 'there' followed by a nominal group functioning as existent (a thing or phenomenon of any kind which exists in the process). Keep in mind that word there, in this case, is not analyzed for transitivity since it does not convey any representational meaning. For instance:

There

Is

a landslide

\section{Process Existent: event}

If existential process represents existence, relational process deals with a relation between two participants. According to Mehmood et al (2014), relational processes can be classified as follows.

1) Attributive relational process

This type of process serves to describe. The participants associated with it are carrier and attribute.

2) Identifying relational process

This type of process serves the purpose of defining. The participants involved are 
token and value in which the value serves to define the identity of the token.

Then, as cited in Suarnajaya (2015), each of those two can be further classified into these following terms:

a) Intensive relational process (' $x$ is $a^{\prime}$ )

An intensive relational process deals with the establishment of the relationship between the participants of each process type, where the word 'be' or its synonym is the main means of establishing this relationship.

b) Circumstantial relational process ( $x$ is at $\left.a^{\prime}\right)$

The circumstance is often expressed in the Attribute, the verb remains intensive, the Attribute will be a prepositional phrase or an adverb of location, manner, cause, etc.

c) Possessive relational process( ' $x$ has $a$ ')

Possessive processes encode meanings of ownership and possession between clausal participants.

As adapted from Bustam (2011), the following tables intend to provide clear explanations and examples related to relational processes.

Table 1: Classifications of relational processes in terms of modes and types

\begin{tabular}{|c|l|l|}
\hline & \multicolumn{1}{|c|}{$\begin{array}{c}\text { (i) } \\
\text { attributive } \\
\text { identifying }\end{array}$} \\
\hline $\begin{array}{c}\text { Intensive } \\
\text { (2) }\end{array}$ & $\begin{array}{l}\text { Her singing } \\
\text { is stunning }\end{array}$ & $\begin{array}{l}\text { - Saitama is } \\
\text { the hero } \\
\text { - The hero is } \\
\text { Saitama }\end{array}$ \\
\hline circumstantial & $\begin{array}{l}\text { The concert } \\
\text { is tonight } \\
\text { was the } \\
\text { third; } \\
\text { - The third }\end{array}$ \\
\hline
\end{tabular}

\begin{tabular}{|c|l|l|}
\hline & & $\begin{array}{l}\text { was } \\
\text { yesterday }\end{array}$ \\
\hline Possessive & Kim has & $\begin{array}{l}\text { The four } \\
\text { cars are } \\
\text { Kim's } \\
\end{array}$ \\
& four cars & Kim's are the \\
& & four cars \\
\hline
\end{tabular}

Table 2: Table of Attributive Clauses

\begin{tabular}{|c|c|c|c|}
\hline Attribute of: & & & \\
\hline $\begin{array}{c}\text { Quality } \\
\text { (intensive) }\end{array}$ & Mr. Crocs & is & greedy \\
\hline Circumstance & Mrs. Tarissa & is & $\begin{array}{l}\text { in the } \\
\text { restroom }\end{array}$ \\
\hline (circumstantial) & $\begin{array}{l}\text { The } \\
\text { celebrations }\end{array}$ & last & all day \\
\hline Possession & $\begin{array}{l}\text { The } \\
\text { computer }\end{array}$ & is & to Ahmad \\
\hline & Ahmad & has & a computer \\
\hline & carrier & process & attribute \\
\hline
\end{tabular}

Table 3: Table of Identifying Clauses

\begin{tabular}{|c|l|c|l|}
\hline $\begin{array}{c}\text { Identification } \\
\text { by: }\end{array}$ & & & \\
\hline $\begin{array}{c}\text { Token - value } \\
\text { (intensive) }\end{array}$ & Makki & is \\
played & $\begin{array}{l}\text { the bassist } \\
\text { guitar }\end{array}$ \\
\hline $\begin{array}{c}\text { Circumstance } \\
\text { (circumstantial) }\end{array}$ & Tomorrow & will be & the first \\
fills up & all disks \\
\hline $\begin{array}{c}\text { Possession } \\
\text { (possessive) }\end{array}$ & $\begin{array}{l}\text { The piano } \\
\text { David }\end{array}$ & is & $\begin{array}{l}\text { David's } \\
\text { the piano }\end{array}$ \\
\hline & Token & process & value \\
\hline
\end{tabular}

Numerous researches had been conducted by using transitivity system to facilitate the discourse analysis. Rohmat, Nurhaeni \& Anggraeni (2018) examined the use of transitivity process and its dominant occurrence in students' descriptive text. Then, Anggun's research (2016) focused on investigating the purpose, schematic structures 
and linguistic features of descriptive text in tenth grade students' English textbook. Unlike the two previous researches, a research conducted by Senjawati (2016), used transitivity analysis on investigating the students' recount text.

In this research, transitivity system was used to analyze report text for ninth grade students. The objective of this research is to figure out the most dominant process used in report text and how it relates with the nature of report text.

\section{RESEARCH METHODS}

This research employed descriptive qualitative design. The data was obtained from two pieces of report text taken from ninth grade's National Exam. The procedures of data analysis were started with dividing each sentence in the selected report text into clauses. The clauses were then identified and classified based on six types of processes in transitivity. To figure out the most dominant process used in the report texts, the frequency of each process in the clauses was calculated. Then, the entire result was elaborated descriptively.

\section{FINDINGS AND DISCUSSION}

As the result of analysis, it can be figured out that there were 29 clauses involved in both of the report texts. It was also found that all of the six processes used in the texts. For better information related to the frequency of the processes, the data is shown in the following table.
Table 4: The Frequency of the Six Processes

\begin{tabular}{|l|c|c|}
\hline $\begin{array}{c}\text { Types of } \\
\text { Process }\end{array}$ & Frequency & Percentages \\
\hline Mental & 3 & $8 \%$ \\
\hline Verbal & 1 & $3 \%$ \\
\hline Behavioral & 1 & $3 \%$ \\
\hline Existential & 4 & $11 \%$ \\
\hline Relational & 11 & $31 \%$ \\
\hline Material & 16 & $44 \%$ \\
\hline \multicolumn{1}{|c|}{ Total } & $\mathbf{3 6}$ & $\mathbf{1 0 0 \%}$ \\
\hline
\end{tabular}

Material process occupies the highest position among the other processes. There are sixteen (44\%) material processes found in both of text. The following are some examples of material clause.

(Sentence 2) Many male grasshoppers make noise ...

S4 Grasshoppers undergo simple (or incomplete) metamorphosis

S5 Eggs hatch into nymphs ...

S6 Nymphs molt many times ...

S15 Grasshoppers Eat plants

The second highest occupied by relational process. There are eleven (31\%) relational processes found in both of text. Some examples of the clauses could be seen as follows.

S22 ... and serves a different purpose in the life of the insect

S20 ... all spark our imaginations

S16 Their predators include birds, beetles, rodents, reptiles, and spiders

S21 ... butterflies and moths have a "complete" life cycle

S23 They are eggs, caterpillars, chrysalises, and colorful butterflies

Next, there are four $(11 \%)$ existential process found. This type of process mainly involves the use of be such as are and is. The following are 
some clauses in which existential process could be seen.

S27 There are still thousands of butterfly species ...

S28 There is much to be learned

S22 there are four separate stages ...

S3 There are about 10,000 different species of grasshoppers

Then, there are three $(8 \%)$ mental processes appear in both of the text. The verbs involved are wondered, means and estimate as seen in the following clauses.

$\begin{array}{ll}\text { S18 } & \text { Have you ever wondered ... } \\ \text { S22 } & \text { This means that ... } \\ \text { S24 } & \text { and scientists estimate ... }\end{array}$

The last two processes, behavioral and verbal process occupy the lowest amount of all. There is only one (3\%) process found for each of those processes. The verb involved in behavioral process is breathe, whereas the one involved in verbal process is describe.

S9 Grasshoppers breathe ...

S27 ... that have not been found or described ...

Based on the result of the analysis, it may be inferred that report text tends to involve material and relational processes. It is proven by their percentages which are higher than the other processes. The nature of the report text itself might affects the text's writers to use material and relational processes so that they are able to give clear information related to the object being described. The use of material process objectively encodes how certain phenomena act or happen in the real world. Meanwhile, the use of relational process serves as the complements of the description of the material process and supplies the readers with the information needed to understand the text.

\section{CONCLUSION}

Upon the analysis of the text above, it can be concluded that Halliday's Systemic Functional Linguistics is an effective device for uncovering the stratagems that writers or speakers use to convince us of their view-points. In line with it, transitivity can be used to assist us in examining the structure of sentences which are represented by processes, the participants involved in these processes, and the circumstances in which processes and participants are involved. Transitivity system consists of six processes that represent human experience in terms of: physical and physiological actions (Material and Behavioral), thinking and speaking actions (Mental and Verbal) and actions that signal the existence of something or someone and their identifying features (Existential and Relational). The analysis conducted reveals that the transitivity structure contributes to the realization of the stylistic features of being objective, argumentative, persuasive and informative. In other words, it is extremely useful to describe the quality, the attribute, definitions or descriptions which provide the readers necessary information or present an idea of the subject under discussion.

\section{REFERENCES}

Anggun, S. K. (2016). An analysis of descriptive text in English textbook using transitivity system (A case study of reading passages). Journal of English and Education, 4(1), 147158. 
Bustam, M. R. (2011). Analyzing clause by Halliday's transitivity system. Jurnal Ilmu Sastra, 6(1), 22-34.

Mehmood, A., Amber, R., Ameer, S., \& Faiz, R. (2014). Transitivity analysis: representation of love in Wilde's The Nightingale and the Rose. European Journal of Research in Social Sciences, 2(4).

Rohmat, N., Nurhaeni, A. A., \& Anggraeni, A. (2018). Transitivity analysis of tenth grade students' descriptive text. PROJECT (Professional Journal of English Education), 1(3), 295-302.

Senjawati, D. (2016). Transitivity analysis of tenth grade students'recount texts. Journal of English and Education, 4(1), 1-22.

Suarnajaya, I.W. (2015). Discourse (Semantic) Analysis [Power Point Slide]. Denpasar: Ganesha University.

Zheng, S., Yang, A., \& Ge, G. (2014). Functional stylistic analysis: Transitivity in English-medium medical research articles. International Journal of English Linguistics, 4(2), 12. 